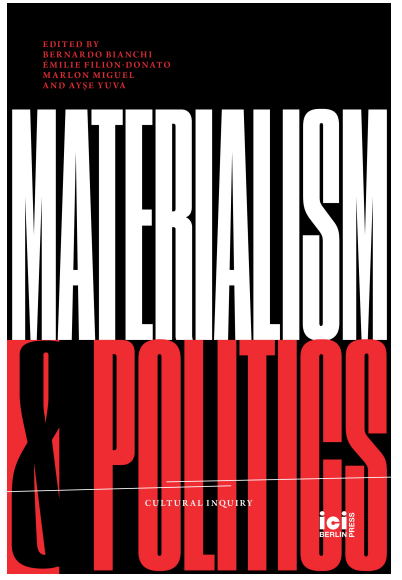

Materialism and Politics, ed. by Bernardo Bianchi, Emilie Filion-Donato, Marlon Miguel, and Ayşe Yuva, Cultural Inquiry, 20 (Berlin: ICI Berlin Press, 2021), pp. 91-106

\section{VITTORIO MORFINO \\ Are there One or Two Aleatory Materialisms?}

\author{
CITE AS:
}

Vittorio Morfino, 'Are there One or Two Aleatory Materialisms?', in Materialism and Politics, ed. by Bernardo Bianchi, Emilie FilionDonato, Marlon Miguel, and Ayşe Yuva, Cultural Inquiry, 20 (Berlin: ICI Berlin Press, 2021), pp. 91-106<https://doi.org/10. 37050/ci-20_05>

\section{RIGHTS STATEMENT:}

(C) by the author(s)

Except for images or otherwise noted, this publication is licensed under a Creative Commons Attribution-ShareAlike 4.0 Interna-

tional License.

ABSTRACT: The chapter will consider the continuity of Althusser's thought and revise my previous interpretation backdating aleatory materialism to the sixties. I will analyse the context in which the concept of 'encounter' emerged in the sixties and show in a second moment that it is possible to identify this concept in the texts of the eighties, but only in one of the two tendencies which traverses this group of texts, the one I would call a materialist tendency. This tendency is intertwined with another tendency, an eschatological one - which emerged in the late seventies.

KEYWORDS: materialism; encounter; void; take hold; eschatology; parousia; Spinozism; Althusser, Louis 


\title{
Are there One or Two Aleatory Materialisms?
}

\author{
VITTORIO MORFINO
}

\section{A LITTLE EXCURSUS CONCERNING MY PREVIOUS INTERPRETATION}

To answer the question of whether there are one or two aleatory materialisms I will introduce and then analyse a series of texts that I have written over the last twenty years concerning Louis Althusser's writings from the eighties.

In primis, I will take into consideration the 'Introduction' that I wrote with Luca Pinzolo for the Italian translation of some of Althusser's writings from the eighties, which was published under the title Sul materialismo aleatorio (On aleatory materialism): the collected texts included 'On Marxist Thought', 'The Underground Current of the Materialism of the Encounter', the two texts that appeared in the journal Lignes on Machiavelli and Spinoza, and the 'Portrait of a Ma- 
terialist Philosopher.' ${ }^{1}$ The book was published in $2000 .^{2}$ In the second edition of 2006, ${ }^{3}$ we added the translation of the text 'On Aleatory Materialism', which had meanwhile been published in the Journal Multitudes. ${ }^{4}$

Our thesis as outlined in the introduction to this volume can be briefly summarized as the continuity between the Althusser of the sixties and the eighties. The implicit polemical objective, although we did not quote him, was undoubtedly an article by Antonio Negri published in a special issue of Futur antérieur (Sur Althusser, Passages) entitled 'Pour Althusser. Notes sur l'évolutions de la pensée du dernier Althusser' (For Althusser: Notes on the Evolution of the Thought of the Last Althusser), ${ }^{5}$ in which he identified a Kehre, or turn, in the thought of the 'last' Althusser.

By contrast, Luca Pinzolo and I argued that in the writings of the 80 s $[. .$.$] Althusser takes up some of the crucial themes [...] of the$ great works of the 60s, Reading Capital and For Marx: those of temporality, contradiction, and complexity' 6 To illustrate this statement, we quoted strategic passages from Althusser's works, such as the 'Outline of the Concept of Historical Time' (1965), 'Contradiction and Overdetermination' (1962), and 'On the Materialist Dialectic' (1963), and again the distinction between whole and totality from 'Is It Simple to Be a Marxist in Philosophy?'(1976).

1 Louis Althusser, 'Sur la pensée marxiste', in Althusser and others, Sur Althusser. Passages (Paris : L’Harmattan,1993), pp. 11-29; 'Le Courant souterrain du matérialisme de la rencontre', in Écrits philosophiques et politiques, ed. by François Matheron, 2 vols (Paris: Stock/IMEC, 1994-95), I (1994), pp. 539-79, in English as 'The Underground Current of the Materialism of the Encounter', in Louis Althusser, Philosophy of the Encounter: Later Writings, 1978-87, ed. by François Matheron and Oliver Corpet, trans. and intro. by Geoffrey M. Goshgarian (London: Verso, 2006), pp. 163-207; 'L'unique tradition matérialiste', ed. by Oliver Corpet, Lignes, 18 (1993), pp. 71-119; 'Portrait d'un philosophe matérialiste', in Écrits philosophiques et politiques, I, pp. 58182, in English as 'Portrait of the Materialist Philosopher', in Althusser, Philosophy of the Encounter, pp. 290-91.

2 Louis Althusser, Sul materialism aleatorio, ed. by Vittorio Morfino and Luca Pinzolo (Milan: Unicopli, 2000).

3 Althusser, Sul materialism aleatorio, ed. by Morfino and Pinzolo, 2nd edn (Milan: Mimesis, 2006).

4 Louis Althusser, 'Du matérialisme aléatoire',Multitude, 21.2 (2005), pp. 179-94 (p. 189).

5 Antonio Negri, 'Pour Althusser. Notes sur l'évolutions de la pensée du dernier Althusser', in Althusser and others, Sur Althusser, pp. 73-96 (p. 83).

6 Vittorio Morfino and Luca Pinzolo, 'Introduzione', in Althusser, Sul materialism aleatorio, pp. 7-12 (p. 8; my translation). 
In addition, we gave particular importance to a passage from 'Contradiction and Overdetermination' in which Althusser criticizes the Marxist theory of revolution as the effect of a simple contradiction between forces of production and relations of production. Concerning the Russian Revolution ('a result of the intense overdetermination of the basic class contradiction'), Althusser writes: 'we should perhaps ask what is exceptional in this "exceptional situation", and whether, like all exceptions, this one does not also clarify its rule - is not, unbeknownst to the rule, the rule itself. After all, are we not always in exceptional situations??

The conclusion of our introduction insisted precisely on this last point: the writings of the eighties take into consideration the complexity of the structure (which was at the centre of Althusser's investigations in the sixties) from the point of view of the 'beginnings and genesis of such complexity'. Given this focus, the distinction between conjuncture and conjunction emerges as important, as does (and especially so) the Epicurean model of the parallel fall of atoms and their encounter made possible by the clinamen. It is important to emphasize that this theme has nothing to do with the revival of a causality by freedom in the Kantian sense, which moreover was always a privileged object of Althusser's criticism. Instead, it concerns the resumption of the theme of complexity as always-already-given, not in the perspective of its revolutionary dissolution but rather of its own aleatory constitution. In this sense, contingency is not opposed to necessity but to teleology. The void and Epicurean atoms are not foundations for freedom but instead the guarantee of the absence of a plan that precedes their encounter. Nothing except the factual circumstances of the encounter has prepared the encounter. This is the meaning of the Althusserian insistence on void and on nothing: not a mystical discourse that renders the void another name for God, but the nothing of all which is not pure facticity. ${ }^{8}$

The second text that I take into consideration is ' $\mathrm{Il}$ materialismo della pioggia di Louis Althusser. Un Lessico' (Louis Althusser's Materialism of the Rain: A Lexicon), which I published in Quaderni

7 Louis Althusser, For Marx, trans. by Ben Brewster (London: Verso, 2005), p. 104; emphasis in the original.

8 Morfino and Pinzolo, 'Introduzione', pp. 10-11. 
materialisti, ${ }^{9}$ in the hope of revealing the systematic structure that can be retraced within the fragmentary nature of the writings of the eighties. As to the question of continuity / discontinuity, I suggested that in these writings it was possible to identify some of the most important themes and problems of the writings of the sixties, even if, undoubtedly, they were contained within a totally different style:

The later texts are above all impressionistic, at times autobiographical, at other times anecdotal. [...] Moreover, all of the texts cited in these essays are recalled from memory, resulting in frequent distortions of the original sources, if not outright inventions. These texts in no way demonstrate the systematicity characteristic of Althusser's two masterpieces from the 1960s, Reading Capital and For Marx, where an entirely new conceptuality was produced through an incisive, close reading of Marx's texts; here, Althusser often transforms his references at will. ${ }^{10}$

Apart from this marked difference in style, I identified the most interesting theoretical element by bringing to the fore 'certain aspects of the texts from the 1960s that have until now remained at the margins (most importantly, the theme of the necessity of contingency)':

This reclamation of earlier marginal moments in Althusser's text is possible due in large part to the insistent deployment of a new constellation of terms $[\ldots]$ :

1. void/nothing;

2. encounter;

3. fact/Faktum/factual/facticity;

4. conjuncture/conjunction;

5. necessity/contingency. ${ }^{11}$

Insisting on the interpretative line of the 'Introduction' I have maintained a close correlation between the concept of void or nothing and the concept of encounter 'such that considering one in isolation will result in altering the nature of both. ${ }^{12}$

9 Vittorio Morfino, 'Il materialismo della pioggia di Louis Althusser. Un Lessico', Quaderni materialisti, 1 (2002), pp. 85-108, in English as 'An Althusserian Lexicon', trans. by Jason Smith, Borderlands, 4.2 (2005) <http://www.borderlands.net.au/ vol4no2_2005/morfino_lexicon.htm>.

10 Ibid.

11 Ibid.

12 Ibid. 
It is precisely from this point that I reopened my reading of the 'last' Althusser, in particular of 'The Underground Current of the Materialism of the Encounter', in an intervention ('Il primato dell'incontro sulla forma') I gave at a conference that took place in Venice in 2004.

The two fundamental gestures I made in this intervention were the affirmation of the rhetorical function of the void and the latent centrality of Charles Darwin. On the void, I said:

I would like to maintain that the emphasis on the concepts of 'nothing,' the 'null' and the 'void' has a purely rhetorical function; that contingency and the aleatory are the effect of an encounter and not of the nothing or the void. If this rhetorical function is transformed into a theoretical proposition, it risks transforming the theory of the encounter into a theory of the event or of freedom. ${ }^{13}$

\section{On Darwin:}

What I would like to argue is that Althusser's position is diametrically opposed to Aristotle's, and that the thesis that is never written apertis verbis in 'The Underground Current' is in fact its fundamental theoretical centre: the primacy of the encounter over form. [...] [This] can be read in a totally new light when we juxtapose it with an author that Althusser refers to only once: Charles Darwin. ${ }^{14}$

I have argued for the centrality of Darwin's role based on the fact that the only time his name was mentioned was in relation to a conference organized in Paris by Dominique Lecourt and Yvette Conry, in which Lecourt presented an intervention entitled 'Marx au crible de Darwin. ${ }^{15}$ In this lecture he placed the English naturalist at the highest point of a philosophy of the encounter which would also include Epicurus and Machiavelli, an intervention that seemed to me at the very least in dialogue with Althusser if not directly inspired by him.

After this little excursus, I am finally able to return to the question posed by my title, namely whether there are 'One or Two Aleatory

13 Vittorio Morfino, Plural Temporality: Transindividuality and the Aleatory between Spinoza and Althusser (Leiden: Brill, 2014), p. 97.

14 Ibid., p. 104.

15 Dominique Lecourt, 'Marx au crible de Darwin', in De Darwin au darwinisme: science et idéologie, ed. by Yvette Conry(Paris: Vrin, 1983), pp. 227-49. 
Materialisms.' Of course, this question resonates with —and polemically opposes - an article published by François Matheron and Yoshihiko Ichida entitled 'Un, deux, trois, quatre, dix mille Althusser. Considérations aléatoires sur le matérialisme aléatoire. ${ }^{16}$ Through the developments outlined in my introduction and the two essays I have quoted, my answer to this question was that there was only one aleatory materialism in continuity with the Althusserian thought of the sixties. And not only! When I found in some unpublished texts from the sixties, that Althusser had used certain categories like 'conjunction', 'encounter', and 'take hold', I ended up backdating aleatory materialism to the sixties. Now, however, I'm asking myself whether this was the right way to think the problem, and whether it is not necessary to first take into consideration the role of these categories in the theoretical context of the sixties and then confront them with the thought of the eighties.

\section{INSTEAD OF GENESIS}

Let us first take into consideration the context in which these categories emerge in the texts from the sixties. They seem to shed light on the question of the disjunction established in Reading Capital between genesis and structure: in other words, the disjunction between the theory of the body, of the actual structure of society (to be even more precise, of the mechanism that produces what Althusser calls the 'society-effect'), and the theory of bourgeois society as a historical result.

It seems to me that Althusser introduced the concepts of encounter and conjunction to solve two problems in his theory that may have a common origin. Firstly, his insistence on the Marxian term Verbindung, which is translated as 'combination' but thought of as 'combinatory', did not allow him to think of the constitutive nature of relations and, secondly and concurrently, did not allow him to clearly conceptualize an alternative to the concept of 'genesis', which he, how-

16 François Matheron and Yoshihiko Ichida, 'Un, deux, trois, quatre, dix mille Althusser. Considérations aléatoires sur le matérialisme aléatoire', Multitude, 21.2 (2005), pp. $167-78$. 
ever, openly refused. I would like to address these two problems in turn in the following paragraphs.

Firstly, in 'The Object of Capital', in particular in the chapter dedicated to Marx's critique of political economy, Althusser stresses Marx's use of the term Verbindung to think the relations of production beyond any model of intersubjectivity. ${ }^{17}$ A Verbindung, or, to return to the terms of the 1857 Introduction, a distribution, is a certain attribution of the means of production to the agents of production, in a certain regular proportion fixed between, on one hand, the means of production and, on the other, the agents of production. ${ }^{18}$ Althusser notes that there are even more distinctions to be found in Marx: on the side of the means of production, there is a distinction between the object and the instruments of production, and on the side of the agents, there is one between the immediate agents of production and the owners of the means of production. Althusser then concludes:

By combining or inter-relating these different elements labour-power, direct workers, masters who are not direct workers, object of production, instruments of production, etc. we reach a definition of the different modes of production which have existed and can exist in human history. ${ }^{19}$

Here Althusser adds an important remark: this Verbindung of the preexisting determinate elements 'would sincerely and truly constitute a combinatory. ${ }^{20}$

In the second edition from 1968, Althusser fine-tunes his analysis, affirming that this operation 'might make us think of a combinatory' but that the specific nature of the relations put into play from these different combinations define and strictly limit the field:

To obtain the different modes of production these different elements do have to be combined, but by using specific modes

17 Louis Althusser, 'L'objet du Capital', in Lire le Capital (Paris: PUF, 1996), pp. 245418 (p. 385), in English as 'The Object of Capital', trans by Ben Brewster, in Reading Capital: The Complete Edition (London: Verso, 2015), pp. 215-355 (p. 329).

18 Ibid., p. 386, eng. tr., p. 329.

19 Ibid., p. 388, eng. tr., p. 330.

20 Althusser and others, 'Variantes de la première édition', in Lire le Capital (Paris: PUF, 1996), pp. 635-61 (p. 645). 
of combination or 'Verbindungen' which are only meaningful in the peculiar nature of the result of the combinatory. ${ }^{21}$

Why did Althusser make this correction? We can suppose that the translation of the term Verbindung with combination and Althusser's further reading of this in terms of a 'combinatory of elements' could make one think of a pre-existence of the elements, which then enter into different relations in different modes of production. The correction Althusser introduces in the second edition of Reading Capital seems to aim at avoiding the risk of thinking of invariable elements combined in different ways in different modes of production.

Regarding the second problem, we can list a series of texts, including the little note 'On Genesis', the letters to René Diaktine, and the 'The Humanist Controversy'. In these texts, the reason for the absence of the concept of 'genesis' appears in full light. In a letter to Diaktine dated 22 August 1966, Althusser insists at length on the question:

Whoever says genesis says the reconstitution of the process through which a phenomenon A has actually been engendered. That reconstitution is itself a process of knowledge: it has meaning (as knowledge) only if it reproduces (reconstitutes) the real process that engendered phenomenon A. You will see immediately that whoever says genesis says from the outset that the process of knowledge is identical in all its parts and in their order of succession to the actual process of engendering. [...] That means, to speak in less abstract terms, that whoever elaborates the genesis of a phenomenon A can follow the tracks, in all its phases, from the origin of the actual process of engendering without any interruption, that is, without any discontinuity, lacuna, or break (the words hardly matter). This immediate and total overlap $[. .$.$] implies the idea [. .$.$] that the$ subject of the real or actual process is a single and same subject, identifiable from the origin of the process to the end. ${ }^{22}$

The 'genesis' paradigm therefore implies a kind of organic unity between the concepts of 'process of generation', 'origin of the process', 'goal or end of the process', 'identity of the subject of the process of

21 Althusser, 'L'objet du Capital', p. 388, eng. tr., p. 331.

22 Althusser to Diaktine, 22 August 1966, in Louis Althusser, Écrits sur la psychanalyse (Paris: Stock/IMEC, 1993), pp. 83-110 (pp. 83-84), in English as Writings on Psychoanalysis: Freud and Lacan, trans. by Jeffrey Mehlman (New York: Columbia University Press, 1996), p. 55. 
generation', unity impregnated by the reference to an experience, the experience of generation, 'be it that of the child who becomes an adult or that of the seed that becomes a vegetal or living being'. In the genetic model, the individual we find at the end of the process, which we are confronted with, is already present in the seed. According to Althusser, this makes the structure of each 'genesis' teleological:

Every genetic thought is literally obsessed by the search for a 'birth', with all that is entailed by the ambiguity of that word, which presupposes $[\ldots]$ the $[\ldots]$ idea that what is to be observed in its very birth already bears its name, already possesses its identity, $[\ldots]$ already exists in some manner before its own birth in order to be born! $!^{23}$

Althusser adds that the concept of 'genesis' - as with any ideological concept - 'recognizes misunderstanding, that is to say, designates a reality by covering it with a false knowledge, an illusion'. The reality that the concept of genesis misunderstands is 'the emergence of the phenomenon A, radically new compared to all that precedes its own emergence':

Whence the imperative of a logic different from that of genesis, but precisely to think that reality and not to dispense with thinking that reality. I have for a long time now been insisting on the necessity of constituting that new logic, which amounts to the same thing as defining the specific forms of a materialist dialectic. $^{24}$

In a short note written exactly one month later on 22 September 1966, entitled 'On Genesis', Althusser gave a name to this new logic which he meant to replace the logic built around the ideological (religious) category of Genesis'. He called it the 'theory of the encounter' or 'theory of the conjunction. A privileged example, as in the letter to Diaktine, is the logic of the constitution of the capitalist mode of production:

23 Ibid., p. 86, eng. tr., p. 57.

24 Ibid., p. 89, eng. tr., p. 59. 
1. the elements defined by Marx 'combine'. I prefer to say (in order to translate the term Verbindung) that they 'conjoin' by 'taking hold' in a new structure. This structure cannot be thought, in its irruption, as the effect of a filiation; it must be thought as the effect of a conjunction. This new Logic has nothing to do with the linear causality of filiation or with Hegelian 'dialectical' causality $[\ldots]$

2. Yet each of the elements that come to be combined in the conjunction of the new structure (in this case to hand, accumulated money-capital; 'free' labour-power, that is, labour-power divested of its work tools; and technological inventions) is itself, as such, a product, an effect.

What is important in Marx's demonstration is that the three elements are not contemporaneous products of one and the same situation. In other words, it is not the feudal mode of production which, by itself, thanks to a providential finality, simultaneously engenders the three elements required for the new structure to 'take hold'. Each of these elements has its own 'history', or genealogy (to borrow a concept from Nietzsche's that Balibar has used felicitously in this connection): the three genealogies are relatively independent. [...]

Thus the genealogies of the three elements are independent of each other, and independent (in their co-existence, in the co-existence of their respective results) of the existing structure (the feudal mode of production). This excludes all possibility of a resurgence of the myth of genesis. ${ }^{25}$

The plurality of genealogies in this passage indicates precisely the opposite of genesis, that is, it indicates the emergence of a plurality of elements that coexist but which are not contemporary effects of the same situation.

We can find a similar critique of the concept of genesis in the 'The Humanist Controversy', picking up on the debate raised in the Marxist field by what Althusser calls 'the recent discoveries of human palaeontology.26 Here, the reference is to André Leroi-Gourhan and

25 Louis Althusser, 'Sur la genèse', in Écrits sur l'histoire (Paris: PUF, 2018), pp. 81-86 (pp. 81-82), in English as 'On Genesis', in History and Imperialism: Writings, 19631986, trans. by Geoffrey M. Goshgarian (Cambridge: Polity, 2020), pp. 33-36 (pp. 33-34).

26 Louis Althusser, 'La querelle de l'humanisme', in Écrits philosophiques et politiques, II (1995), pp. 433-532 (p. 504), in English as 'The Humanist Controversy', in his The 
his theory that 'the "ancestor" of the human line ${ }^{\text {,27 }}$ is a being that, while only having a modestly developed brain, has the distinctive particularity of an upright position and free hands for making instruments under conditions which are social and not individual. These discoveries would seem to fill in the gap separating current human societies from the animal origins of the human species, because from its origins onwards the human species would be constituted by beings who lived together and produced rudimentary instruments. In this regard, Althusser cites Jean Suret-Canale who, on the basis of Leroi-Gourhan's theory, claimed that social labour is the original cause of humanization. ${ }^{28}$ Criticizing this position on the question of anthropogenesis, Althusser focused on the spontaneous persistence of a conception that cannot resist associating materialism and genesis. ${ }^{29}$

Genesis signifies filiation - it signifies that we are dealing with one individual whose transformations we can follow in the spontaneous form of an empiricism that weaves a continuous thread. Just as it seems to break with a genetic scheme, the genesis of man from ape introduces another genetic scheme within the human kingdom which identifies the originary individual. Althusser writes:

The Originary Individual; he has been identified, he makes 'tools' of some unspecified sort, he lives in groups: he's the one, all right. ${ }^{30}$

Althusser opposes a theory of the encounter against this schema of the 'originary', the privileged example of which is the capitalist mode of production as the result of a process that does not have the form of a genesis. Remaining within the metaphor of filiation, Althusser writes:

We must go much further, and say that the Sons who count in the historical process have no father, because they need several, and these fathers are in their turn the sons not of a single father $[\ldots]$, but of several. ${ }^{31}$

Humanist Controversy and Other Writings (1966-67), trans. by Geoffrey M. Goshgarian (London: Verso, 2003), pp. 221-305 (p. 284).

27 Ibid., p. 505, eng. tr., p. 284.

28 Ibid., p. 508, eng. tr., p. 286.

29 Ibid., p. 515, tr. eng., pp. 292-93.

30 Ibid., p. 517, tr. eng., p. 294.

31 Ibid., p. 520, eng. tr., p. 296. 
As we have seen, the critique of the concept of genesis is constantly accompanied by the historical example of primitive accumulation. ${ }^{32}$ The other example found in Althusser's texts is that of the unconscious. In the letter to Diaktine from 22 August 1966, Althusser writes:

When one wants to think through the 'genesis' of the unconscious, $[\ldots]$ one starts with the result within knowledge, namely, the existence of that identified 'individual' called the unconscious, and elaborating the genesis of the unconscious consists in moving back to its birth, to the point at which one witnesses its birth, but one manages only with difficulty to rid oneself of the idea that in a certain way, to elaborate the genesis of the unconscious means to seek out, even before its birth, all that already prefigures and announces it, already contains it in person, even in the form of a draft, but that resembles it and that is already it, that already bears its name, that is already identifiable $[\ldots]$. One has the greatest difficulty conceiving that prior to the unconscious absolutely nothing exists that resembles the unconscious; one always tends to recognize it in germ, as a promise, draft, element, prefiguration, etc., before its own birth precisely because one conceives its irruption in the form of a birth. $^{33}$

Althusser thus rejects the concepts of genesis and birth in favour of concepts such as 'encounter', 'taking hold', 'conjunction. We can take as an example this passage from the Three Notes on Discourse Theory:

We can $[\ldots]$ set out the elements which are present and 'preside' over the conjunction that 'takes hold' in the form of the unconscious. [...] The elements involved exist in the characters of the familial theatre, the familial situation: an ideological 'situation' in which are produced, as constitutive of this 'situation', the effects of the articulation of the mother's and father's unconscious with and in the structure of this ideological situation. Unconsciouses articulated with the ideological, unconsciouses articulated with each other by way of (in) their articulation with the ideological: this is what constitutes the 'situation' that presides over the establishment of the unconscious in the child. ${ }^{34}$

32 Cf. Althusser's 22 August 1966 letter to René Diaktine, p. 61.

33 Althusser to Diaktine, 22 August 1966, p. 87, eng. tr. p. 58.

34 Louis Althusser, 'Trois notes sur la théorie du discours', in Écrits sur la psychanalyse, pp. 111-70 (pp. 146-47), in English as 'Three Notes on the Theory of Discourses', in The Humanist Controversy and Other Writings, pp. 33-84 (p. 62; emphasis in the original). 
It is interesting to remark that the concept of the 'void' also has a role between the set of concepts used to substitute the scheme of the genesis, but in very precise way, as a 'determinate absence':

I believe you will agree with the very general principle that absence possesses a certain efficacy on the condition, to be sure, that it be not absence in general, nothingness or any other Heideggerian 'openness' but a determinate absence playing a role in the space of its absence. ${ }^{35}$

One might perhaps advance the hypothesis that this 'theory of the encounter' intervenes in these texts of the sixties as a rectification of a formalist theory of structural causality, or at least the potential risk of such a theory. In other words, it seems to me that the functioning of the theory of structural causality is secured by three theses: 1) the thesis of the constitutiveness of relations; 2) the thesis of the primacy of the encounter over the form; 3 ) and the thesis of plural or differential temporality. Now, these three theses must be thought in an intertwined fashion. In fact, $\mathrm{T} 1$ without $\mathrm{T} 2$ produces the reversibility of genesis and structure or the impossibility of thinking the becoming of the structure, $\mathrm{T} 2$ without $\mathrm{T} 3$ leads to think the encounter as a discontinuous event in a unique time-line, and $\mathrm{T} 3$ without $\mathrm{T} 1$ ends up thinking a multiplicity of unrelated times.

\section{THE TEXTS OF THE EIGHTIES}

Finally, we can address the content of the writings from the eighties, where a series of concepts persists: the 'encounter', 'taking hold', 'constitutive relations'. This persistence may make us think that we are dealing with the same materialism of the sixties, and the privileged example of primitive accumulation also returns, even if the reference to psychoanalysis and the unconscious disappear completely. I would argue that this conceptual constellation constitutes one of the two tendencies present in these writings, namely what I have called here the materialist tendency; indeed, besides these concepts, we find others whose history of appearance in Althusserian thought remains to be written, for example the Deleuzian concept of 'rhizome', the Marxian

35 Althusser to Diaktine, 22 August 1966, p. 90, eng. tr., pp. 60-61. 
concept of interstice or the pair margin-centre. Allow me to quote a passage on the Theses of June on the rhizome and interstice:

The world is now an unpredictable flow. If we want to give an image, we must go back to Heraclitus (we do not bathe twice in the same river), or Epicurus (primacy of void on the atomic corpuscles). If we want to give a closer image, following in this Deleuze $[\ldots]$ we must not represent the world according to Descartes as a hierarchical tree, but rather as a rhizome. For me, I would prefer another image, that of Marx. Marx said: the gods exist in the interstices of the world of Epicurus. He added: in the same way, commercial relations existed in the interstices of the slave world. I would say the same thing: communist relations (communism is the end of the relations of economic exploitation, the end of state domination and the end of ideological mystifications) exist in the interstices of the imperialist world. ${ }^{36}$

And here a passage on the pair margin-centre:

Marx said: the proletariat camps on the margins of bourgeois society. And he put it in the centre, at the heart of the class struggle of bourgeois society. What was Marx doing? He made of the margin the centre. The problem today is formally the same. You have to make the margin the centre. ${ }^{37}$

Of course, the use of these concepts, although rare and episodic, sketches a different tendency than the one we have designated as the materialist one - which is rooted in the sixties' problematic - and which we could define as eschatological to the extent that it, on the one hand, rejects the hierarchical structure of the whole (which means, at the same time, the temporal complexity of the conjuncture) and, on the other, and as a consequence of this, affirms communism as simple parousia to come.

In this sense, the illuminating concept of the conflicting presence of these two tendencies in the texts of the eighties is precisely that of void: it is an expression of the materialist tendency if thought in a triangulation with the concepts of clinamen and atomic elements (we could say that void, clinamen, and atoms are the conceptual tools that

36 Louis Althusser, Thèse de juin, IMEC, ALT2. A29.60.04, p. 9.

37 Ibid., p. 12. 
render a theory of encounter or of conjunction thinkable), and within this conceptual relationship it expresses the simple rejection of the anteriority of the logos, of the genesis; nevertheless, when it is thought in connection with the concept of world it became an expression of the eschatological tendency (of course there are some passages in which the two tendencies intersect each other). Here is an example:

I simply want to say that this world, empty of any assured and stable structure, empty of theory, depoliticized to the extreme [... ] I simply want to say that this world offers itself and that it is to take. I studied the theme of 'fortune' (the good occasion) in Machiavelli, and I came to the conclusion that fortune in its higher form is the void: the absence of obstacles. ${ }^{38}$

If we try to lend systematicity to this set of concepts (forcing them, perhaps) it seems to me that they shape the second tendency present in the writings on aleatory materialism (a tendency which predominates in the writings of 1985-86), an eschatological tendency in which the void must become full, the margins centre, the interstices worlds, where absence does not have a determinate character but is rather the expectation of a full parousia, which the theory of structural causality of the sixties had considered as both impossible and imaginary:

What reigns in silence is a big wait $!^{39}$

\section{CONCLUSION}

To conclude, I propose the following interpretative schema. If we take the writings of the eighties as a whole (something that Luca Pinzolo and I did by publishing them with the title On Aleatory Materialism) we can find the re-elaboration of the material deposits in two different temporal streams, the first one which comes from the years 1966-67 (I would call it the materialist tendency), the second from the years $1976-78^{40}$ (the eschatological tendency). One can perhaps ascribe to

\footnotetext{
38 Ibid., p. 10.

39 Louis Althusser, 'Sur le matérialisme aléatoire', p. 189.

40 I am thinking particularly of some passages on communism in Louis Althusser, Les Vaches noires. Interview imaginaire (Paris: PUF, 2016), pp. 251-67 or on the margins in Etre marxiste en philosophie (Paris: PUF, 2015), pp. 212-16.
} 
the first tendency the new elaboration of the materials leavened by a second stream, coming from the beginning of the seventies with the courses on Rousseau and Machiavelli and the text on Imperialism. ${ }^{41}$ Of course the two tendencies produce a tension which traverses the writings and the concepts of these years, a tension that can perhaps explain the different, if not opposing, interpretations the writings of these years have produced.

However, perhaps it is possible to take a step further and risk an hypothesis that could only be proven with precise and rigorous work on these texts, a part of which has not yet been published: ${ }^{42}$ one could try a more precise periodization of these writings by saying that in the writings of 1982 there is a dominance of the materialist tendency, whereas in the writings of 1985-86 there is a dominance of the eschatological tendency.

41 Louis Althusser, Machiavelli et nous, in Ecrits philosophiques et politiques, II, pp. 39167; Louis Althusser, Cours sur Rousseau, ed. by Yves Vargas (Paris: Les temps de Cerises, 2012); Louis Althusser, 'Sur l'impérialisme', in Écrits sur l'histoire, pp. 103260. In any case an important reconstruction of this stream of thought can be found in Stefano Pippa, Althusser and Contingency (Milan: Mimesis International, 2018).

42 I'm referring to the group of text that are listed in the Althusser archive as ALT2.029 (Textes divers, 1982-1986). 
Vittorio Morfino, 'Are there One or Two Aleatory Materialisms?', in Materialism and Politics, ed. by Bernardo Bianchi, Emilie Filion-Donato, Marlon Miguel, and Ayşe Yuva, Cultural Inquiry, 20 (Berlin: ICI Berlin Press, 2021), pp. 91-106<https: //doi.org/10.37050/ci-20_05>

\section{REFERENCES}

Althusser, Louis, 'Le Courant souterrain du matérialisme de la rencontre', in Écrits philosophiques et politiques, I (1994), pp. 539-79

- Cours sur Rousseau, ed. by Yves Vargas (Paris: Le Temps des cerises, 2012) 'Du matérialisme aléatoire', Multitude, 21.2 (2005), pp. 179-94 <https://doi.org/10. 3917/mult.021.0179>

_Écrits philosophiques et politiques, ed. by François Matheron, 2 vols (Paris: Stock/IMEC, 1994-95)

_Écrits sur l'histoire (Paris: PUF, 2018) Écrits sur la psychanalyse (Paris: Stock/IMEC, 1993)

_Etre marxiste en philosophie (Paris: PUF, 2015) <https://doi.org/10.3917/puf.althu. 2015.01>

_ For Marx, trans. by Ben Brewster (London: Verso, 2005)

_ 'The Humanist Controversy', in The Humanist Controversy and Other Writings (1966-67), trans. by Geoffrey M. Goshgaran (London: Verso, 2003), pp. 221-305

_ Letter to Diaktine, 22 August 1966, in Louis Althusser, Écrits sur la psychanalyse (Paris: Stock/IMEC, 1993), pp 83-110

— 'Machiavel', in L'Unique tradition matérialiste, ed. by Corpet, pp. 99-119 <https://doi. org/10.3917/lignes0.018.0099>

- Machiavelli et nous, in Ecrits philosophiques et politiques, II, pp. 39-167

_ 'The Object of Capital', trans by Ben Brewster, in Althusser and others, Reading Capital: The Complete Edition (London: Verso, 2015), pp. 215-355

_ 'L'objet du Capital', in Althusser and others, Lire le Capital (Paris: PUF, 1996), pp. 245418

'On Genesis', in History and Imperialism: Writings, 1963-1986, ed. and trans. by Geoffrey M. Goshgarian (Cambridge: Polity, 2020), pp. 33-36

_ Philosophy of the Encounter: Later Writings, 1978-87, ed. by François Matheron and Oliver Corpet, trans. and intro. by Geoffrey M. Goshgarian (London: Verso, 2006)

'Portrait d'un philosophe matérialiste', in Écrits philosophiques et politiques, I, pp. 581-82 'Portrait of a Materialist Philosopher', in Philosophy of the Encounter, pp. 290-91

'La querelle de l'humanisme', in Écrits philosophiques et politiques, II (1995), pp. 433-532 'Spinoza', in L'Unique tradition matérialiste, ed. by Corpet, pp. 75-97 <https://doi.org/ 10.3917/lignes0.018.0075>

_ Sul materialismo aleatorio, ed. by Vittorio Morfino and Luca Pinzolo, 1st edn (Milan: Unicopli, 2000); 2nd edn (Milan: Mimesis, 2006)

'Sur la genèse', in Écrits sur l'histoire, pp. 81-86

'Sur l'impérialisme', in Écrits sur l'histoire, pp. 103-260 
—_ 'Sur la pensée marxiste', in Althusser and others, Sur Althusser, pp. 11-29

Thèse de juin, IMEC, ALT2. A29.60.04

— 'Three Notes on the Theory of Discourses', in The Humanist Controversy and Other Writings, pp. 33-84

— 'Trois notes sur la théorie du discours', in Écrits sur la psychanalyse, pp. 111-70

— 'The Underground Current of the Materialism of the Encounter', in Philosophy of the Encounter, pp. 163-207

L Les Vaches noires. Interview imaginaire (Paris: PUF, 2016) <https://doi.org/10.3917/puf. althu.2016.01>

Writings on Psychoanalysis: Freud and Lacan, trans. by Jeffrey Mehlman (New York: Columbia University Press, 1996)

Althusser, Louis, and others, Sur Althusser. Passages (Paris: L'Harmattan, 1993)

_ 'Variantes de la première édition', in Lire le Capital (Paris: PUF, 1996), pp. 635-61

Corpet, Oliver, ed., L’Unique tradition matérialiste (=Lignes, 18.1 (1993), pp. 71-119) <https: //doi.org/10.3917/lignes0.018.0071>

Lecourt, Dominique, 'Marx au crible de Darwin', in De Darwin au darwinisme: science et idéologie, ed. by Yvette Contry(Paris: Vrin, 1983), pp. 227-49

Matheron, François, and Yoshihiko Ichida, 'Un, deux, trois, quatre, dix mille Althusser. Considérations aléatoires sur le matérialisme aléatoire’, Multitude, 21.2 (2005), pp. 167-78 <https://doi.org/10.3917/mult.021.0167>

Morfino, Vittorio, 'An Althusserian Lexicon', trans. by Jason Smith, Borderlands, 4.2 (2005) <http://www.borderlands.net.au/vol4no2_2005/morfino_lexicon.htm> [accessed 15 November 2020]

'Il materialismo della pioggia di Louis Althusser. Un Lessico', Quaderni materialisti, 1 (2002), pp. 85-108

- Plural Temporality: Transindividuality and the Aleatory between Spinoza and Althusser (Leiden: Brill, 2014) <https://doi.org/10.1163/9789004270558>

Morfino, Vittorio, and Luca Pinzolo, 'Introduzione', in Althusser, Sul materialism aleatorio, pp. $7-12$

Negri, Antonio, 'Pour Althusser. Notes sur l'évolutions de la pensée du dernier Althusser', in Althusser and others, Sur Althusser, pp. 73-96

Pippa, Stefano, Althusser and Contingency (Milan: Mimesis International, 2018) 